Egypt. Acad. J. Biolog. Sci., 4(1): 107-112 (2012)

Email: egyptianacademic@yahoo.com

Received: 11/9/2012
C. Physiology \& Molecular Biology

ISSN: 2090-0767

www.eajbs.eg.net

\title{
Evaluation of plasma leptin levels in Sudanese diabetic patients
}

\author{
Ahmed Mohammed Ahmed \\ Taibah University - College of Applied Medical Sciences-Laboratory Department- \\ KSA- Almadinah Almunawara. \\ E.mail: ahmedlab1@hotmail.com
}

\begin{abstract}
Background

Leptin is an adipose tissue-derived hormone shown to be involved in pathophysiological mechanisms related to diabetes. Few studies examined the association between plasma leptin and diabetes mellitus in humans. Therefore, we examined the association between plasma leptin levels and diabetes in a Sudanese diabetic patient's compared with a healthy subjects regarded by different parameters.
\end{abstract}

\section{Methods:}

We examined the 1272 participants $20-70$ years of age, 872 diabetic patients and 400 control healthy subjects, in different hospitals in (Khartoum-Sudan) during the period $1 / 4 / 2012$ to $1 / 9 / 2012$. Plasma leptin levels, total cholesterol were determined categorized by BMI, sex and smoking habits in all study subjects.

\section{Results:}

There were significant associations between plasma leptin levels and diabetes mellitus after adjusting for BMI, smoking and serum cholesterol level ( $\mathrm{P}$ value $<$ 0.01). But there were insignificant association between plasma leptin levels and diabetes mellitus after adjusting of both men and women.

\section{Conclusion:}

Plasma leptin levels are independently associated with diabetes mellitus after adjustment for BMI, total cholesterol and smoking.

Key words: Leptin, BMI categories, diabetes, obesity.

\section{INTRODUCTION}

Leptin is an adipose tissue-derived hormone that has been shown to be related to several metabolic, inflammatory, and homeostatic factors involved in the development of hypertension and cardiovascular disease and diabetes. (Wannamethee SG et al., 2007).

Human leptin is a protein of 167 amino acids. It is manufactured primarily in the adipocytes of white adipose tissue, and the level of circulating leptin is proportional to the total amount of fat in the body.

In addition to white adipose tissuethe major source of leptin-it can also be produced by brown adipose tissue, placenta (syncytiotrophoblasts), ovaries, skeletal muscle, stomach (the lower part of the fundic glands), mammary epithelial cells, bone marrow, pituitary, and liver. (Margetic S et al., 2002).

Leptin has traditionally been regarded as a link between fat mass, food intake, and energy expenditure. This link originally arose from animal research findings, but its application to describing human systems has since been challenged.(Pilon B, 2011) In humans, many instances are seen where leptin dissociates from the strict role of communicating nutritional status between body and brain and no longer correlates with body fat levels. Leptin level is decreased after short-term fasting (24-72 hours), even when changes in fat mass are not observed.(Chan JL et al., 2003) Leptin level is increased by perceived emotional stress.(Otsuka R et al., 2006) Leptin level is chronically reduced by physical exercise training.(de Salles BF et al., 2010) 
Although leptin reduces appetite as a circulating signal, obese individuals generally exhibit an unusually high circulating concentration of leptin.(Considine RV et al., 1996) These people are said to be resistant to the effects of leptin, in much the same way that people with type 2 diabetes are resistant to the effects of insulin. The sustained high concentrations of leptin from the enlarged adipose stores result in leptin desensitization. The pathway of leptin control in obese people might be flawed at some point, so the body does not adequately receive the satiety feeling subsequent to eating. Some researchers attempted to explain the failure of leptin to prevent obesity in modern humans as a metabolic disorder, possibly caused by a specific nutrient or a combination of nutrients not present or uncommon in the prehistoric diet. Some proposed "villain" nutrients include lectins and fructose (Alexandra Shapiro etal, 2008). A large intake of calories triggers a leptin response that reduces hunger, thereby preventing an overload of the inflammatory response induced by caloric intake. In obese individuals, the leptin response to caloric intake is theorized to be blunted due to chronic, low-grade hyperleptinemia, depressing the signal-to-noise ratio such that acute leptin responses have less of a physiological effect on the body. Although leptin resistance is sometimes described as a metabolic disorder that contributes to obesity, similar to the way insulin resistance is sometimes described as a metabolic disorder that has the potential to progress into the type 2 diabetes, it is not certain that it is true in most cases. The mere fact that leptin resistance is extremely common in obese individuals suggests it may simply be an adaptation to excess body weight. The major physiological role of leptin is suggested to be not as a "satiety signal" to prevent obesity in times of energy excess, but as a "starvation signal" to maintain adequate fat stores for survival during times of energy deficit, and leptin resistance in overweight individuals is the standard feature of mammalian physiology, which possibly confers a survival advantage.(Ashwini Oswal and Giles Yeo, 2010) Animal studies suggest that there is an inverse relationship between leptin levels and insulin secretion.(Kieffer TJ et al., 1997), (Kulkarni RN et al., 1997) Also, it has been suggested that the association between plasma leptin and diabetes may be a manifestation of an underlying leptin resistance mediated by obesity (Steinberg GR et al., 2002). In this study, we examined the association between plasma leptin levels and diabetes in a Sudanese diabetic samples regarded by gender and BMI categories.

\section{MATERIALS AND METHODS}

The patients were a group of 872 (488 male; 384 female) Sudanese patients attended in the outpatients clinic of medicine in different hospitals in Khartoum the capital of the Sudan, during the period from $1 / 4 / 2012$ to $1 / 9 / 2012$. Patients with clinical history of hypertension and alcohol intake and had been excluded. Compared to 400 (220 male; 180 female) control healthy subjects. Plasma leptin levels, total cholesterol were determined in all groups (patients and controls). BMI calculated in all groups. Information of smoking habits (are you current smoker, former smoker or non smoker) in obtained from patients by direct question and reported in questionnaire form. Ethical considerations: The objectives of study were explained to all individuals participating in this study, an informed consent was obtained from all participants with the questionnaire.

Fasting blood sample were collected from all subjects (patients and controls) when they were fasting, $(4 \mathrm{ml})$ in plain containers using disposable syringes, All blood samples were allowed to clot at room temperature and then centrifuged at 4000 R.P.M to obtain the serum. Lipemic samples were cleared by ultracentrifugation. Fibrin formation due to centrifuging of serum samples before a complete formation of clot is avoided to prevent erroneous results due to the 
presence of fibrin. Some samples particularly those from patients receiving anticoagulant therapy, required increased clotting time. Specimens of about (800$1000 \mu \mathrm{l})$ serum were preserved at 2-8 $\mathrm{C}^{\circ}$ prior to processing. Fasting plasma leptin concentrations were determined with a highly sensitive commercial doubleantibody RIA (Human Leptin Specific RIA Kit; Linco Research, Inc., St. Louis, MO). Total Cholesterol measurement by standard laboratory procedure with commercial kit (Biosystems lab. Company Spain).

Body mass index (BMI): was calculated from standard formula $(\mathrm{Kg} / \mathrm{m} 2)$. Statistical analysis: the data were analyzed SPSS version 11.5, t-test used for analysis and the probability $\mathrm{P}<0.01 \quad$ consider significant.

\section{RESULTS}

The mean level of leptin obtained was $21.6 \pm 7.3 \mu \mathrm{g} / \mathrm{L}$ in patients group, and $13.2 \pm 4.9$ in control subjects. The mean level of Total cholesterol obtained was $198.3 \pm 22.4$ and $160.2 \pm 16.2$ in control subjects. The results of this study show that plasma leptin concentrations in patient's group increase with body mass index (Table 1). Table 2 documented that plasma leptin concentration in patient's group increases with body mass index, total cholesterol and smoking habits.

Table 1: Characteristics of the study populations

\begin{tabular}{lcc}
\hline Characters & Patients & Control \\
\hline Number of study groups $(\mathrm{DM})$ & 872 & 400 \\
Sex: male+female & $488+384$ & $220+180$ \\
Age/year & $41.4 \pm 3.5$ & $40.1 \pm 4.2$ \\
Leptin levels $(\mu \mathrm{g} / \mathrm{L})$ & $21.6 \pm 7.3^{*}$ & $13.2 \pm 4.9$ \\
Body max index $(\mathrm{kg} / \mathrm{m} 2)$ & $26.1 \pm 3.4$ & $23.4 \pm 2.8$ \\
Never smoker & 574 & 400 \\
Former smoker & 89 & 0 \\
Current smoker & 209 & 0 \\
Total cholesterol $(\mathrm{mg} / \mathrm{dL})$ & $198.3 \pm 22.4^{* *}$ & $160.2 \pm 16.2$
\end{tabular}

The table shows data as mean values \pm standard deviation

* Leptin levels shows significant different between patient's and control

** Total cholesterol levels shows significant different between patient's and control

Table 2: Comparison of leptin level in different categorized of patients

\begin{tabular}{lc}
\hline Leptin levels & Patients \\
\hline Male & $15.8 \pm 10.2$ \\
Female & $16.6 \pm 8.6$ \\
Smoking: & \\
$\quad$ Never smoker & $9.3 \pm 1.7$ \\
$\quad$ Former smoker & $9.8 \pm 3.1$ \\
$\quad$ Current smoker & $18.9 \pm 2.1^{\mathrm{a}}$ \\
Body max index $(\mathbf{k g} / \mathbf{m} 2):$ & \\
Normal weight $\left(\mathrm{BMI}<25 \mathrm{~kg} / \mathrm{m}^{2}\right)$ & $7.3 \pm 2.2$ \\
Overweight $\left(\mathrm{BMI} 25-29 \mathrm{~kg} / \mathrm{m}^{2}\right)$ & $17.8 \pm 10.2^{\mathrm{b}}$ \\
$\quad$ Obese $\left(\mathrm{BMI} \geq 30 \mathrm{~kg} / \mathrm{m}^{2}\right)$ & $22.6 \pm 14.3^{\mathrm{bb}}$ \\
Total cholesterol $(\mathbf{m g} / \mathbf{d L}):$ & \\
$\quad$ Normal cholesterol level & $10.6 \pm 1.6$ \\
high cholesterol level & $16.3 \pm 4.3^{\mathrm{c}}$ \\
\hline
\end{tabular}

The table shows data as mean values \pm standard deviation

${ }^{a}$ Significant compared to never smoker and former smoker

b Significant compared to normal weight

${ }^{\mathrm{bb}}$ Significant compared to normal weight and overweight ( $\mathrm{P}$ value $\leq 0.01$ consider significant).

${ }^{c}$ Significant compared to normal cholesterol level 


\section{DISCUSSION}

Leptin is an important adipose tissue-derived hormone that has been shown to be involved in pathophysiological mechanisms related to cardiovascular disease and diabetes. However, few studies have examined the association between plasma leptin and diabetes mellitus in humans. Also, it is not clear if this association is present among women as well as in men. Therefore, we examined the association between plasma leptin levels and diabetes mellitus in a representative multiethnic sample of Sudanese adults (Bandaru P and Shankar A, 2011).

In different hospitals in Khartoum the capital of the Sudan, we found that higher plasma leptin levels were independently associated with diabetes mellitus, after adjustment for BMI, smoking and total cholesterol level. But there were independent association when categorized by gender, $(\mathrm{p}<0.01$, Table 2$)$. Also in subgroup analysis by BMI categories, we found that significant different between normal, overweight and obese subjects. Previous studies examining the association between serum leptin levels and diabetes mellitus were restricted to specific racial/ethnic groups and were not consistent in their findings. Some studies reported that there is no association between plasma leptin levels and diabetes, (Haffner SM, et al., 1996) (Maahs DM et al., 2009) but other studies reported significant positive associations between plasma leptin levels and diabetes only in men (Wannamethee SG et al., 2007) (Welsh P et al., 2009); however, Sun et al., reported an inverse relation (Sun Q et al., 2010). The different results in previous studies may be due to differences in the inclusion or exclusion of one or two important confounding variables. a positive association was observed between leptin and diabetes mellitus even after adjusting for age, sex, race-ethnicity, education, smoking, serum total cholesterol. Our study supported by finding of Considine et al., who suggested that leptin levels are closely related to body fatness (Considine RV et al., 1996). Also supported by Velasque et al., reports, that plasma leptin may be a good biomarker of obesity (Velasque MT et al., 2001). Therefore, an association between plasma leptin and diabetes mellitus may be mediated by body fat same like finding of Kanaya (Kanaya AM et al., 2006). Higher leptin levels, conjunct with obesity and weight gain are probably involved in the subsequent development of diabetes, consistent with previous studies, (Shamsuzzaman AS et al., 2004), (Viikari LA et al., 2007).

The main strengths of our study is a large sample size that enabled us to perform separate analysis by gender and BMI categories suggests that our findings are less likely due to chance.

\section{CONCLUSION}

We found that plasma leptin levels are associated with diabetes mellitus, categorized of BMI. Plasma leptin was not associated with diabetes in men and women.

\section{REFERENCES}

Alexandra Shapiro, Wei $\mathrm{Mu}$, Carlos Roncal, Kit-Yan Cheng, Richard J. Johnson, and Philip J. Scarpace (2008). "Fructose-induced leptin resistance exacerbates weight gain in response to subsequent high-fat feeding". American journal of physiology. Regulatory, integrative and comparative physiology, 295 (5): R1370-R1375.

Ashwini Oswal, Giles Yeo (2010). "Leptin and the Control of Body Weight: A Review of Its Diverse Central Targets, Signaling Mechanisms, and Role in the 
Pathogenesis of Obesity". Obesity,18 (2): 221-229.

Bandaru, P. and Shankar, A. (2011). Association between plasma leptin levels and diabetes mellitus. Metab Syndr Relat Disord., 9(1):19-23.

Chan, JL.; Heist, K.; DePaoli, AM.; Veldhuis, JD. and Mantzoros, CS. (2003). "The role of falling leptin levels in the neuroendocrine and metabolic adaptation to short-term starvation in healthy men". J. Clin. Invest., 111 (9): 1409-1421.

Considine, RV.; Sinha, MK.; Heiman, ML.; Kriauciunas, A.; Stephens, TW.; Nyce, MR.; Ohannesian, JP.; Marco, CC.; McKee, LJ. and Bauer, TL. (1996). "Serum immunoreactiveleptin concentrations in normalweight and obese humans". N. Engl. J. Med., 334 (5): 292-295.

De Salles, BF.; Simão, R.; Fleck, SJ.; Dias, I.; Kraemer-Aguiar, LG. and Bouskela, E. (2010). "Effects of resistance training on cytokines". Int J Sports Med, 31 (7): 441-450.

Haffner, SM.; Stern, MP.; Miettinen, H.; Wei, M. and Gingerich, RL. (1996). Leptin concentrations in diabetic and nondiabetic Mexican-Americans. Diabetes, 45:822-824.

Kanaya, AM.; Wassel, FC.; Vittinghoff, E.; Harris, TB.; Park, SW.; Goodpaster, BH.; Tylavsky, F. and Cummings, SR. (2006). Adipocytokines and incident diabetes mellitus in older adults: the independent effect of plasminogen activator inhibitor 1. Arch Intern. Med, 13(166):350-356.

Kieffer, TJ.; Heller, RS.; Leech, CA.; Holz, GG. and Habener, JF. (1997). Leptin suppression of insulin secretion by the activation of ATPsensitive $\mathrm{Kp}$ channels in pancreatic beta-cells. Diabetes., 46:1087-1093.

Kulkarni, RN.; Wang, ZL.; Wang, RM.; Hurley, JD.; Smith, DM.; Ghatei, MA. Withers, DJ.; Gardiner, JV.; Bailey, CJ. and Bloom, SR. (1997).
Leptin rapidly suppresses insulin release from insulinoma cells, rat and human islets and, in vivo, in mice. J. Clin Invest, 100:2729-2736.

Maahs, DM.; Hamman, RF.; D’Agostino, R. Jr.; Dolan, LM.; Imperatore, G.; Lawrence, JM.; Marcovina, SM.; Mayer-Davis, EJ.; Pihoker, C. and Dabelea, D. (2009). The association between adiponectin/leptin ratio and diabetes type: the SEARCH for Diabetes in Youth Study. J. Pediatr, 155:133-135, 135.

Margetic, S.; Gazzola, C.; Pegg, GG. and Hill, RA. (2002). "Leptin: a review of its peripheral actions and interactions". Int. J. Obes. Relat. Metab. Disord., 26(11): 1407-1433.

Otsuka, R.; Yatsuya, H.; Tamakoshi, K.; Matsushita, K.; Wada, K. and Toyoshima, H. (2006). "Perceived psychological stress and serum leptin concentrations in Japanese men". Obesity (Silver Spring), 14 (10): 1832-1838.

Pilon B. "Leptin and Inflammation Theory". Press75.com. Retrieved 2011-04-19.

Shamsuzzaman, AS.; Winnicki, M.; Wolk, R.; Svatikova, A.; Phillips, BG.; Davison, DE.; Berger, PB. and Somers, VK. (2004). Independent association between plasma leptin and C-reactive protein in healthy humans. Circulation, 109:2181-2185.

Steinberg, GR.; Parolin, ML.; Heigenhauser, GJ.; Dyck, DJ. (2002). Leptin increases FA oxidation in lean but not obese human skeletal muscle: evidence of peripheral leptin resistance. Am J Physiol Endocrinol Metab, 283:E187-E192.

Sun, Q.; van, Dam RM.; Meigs, JB.; Franco, OH.; Mantzoros, CS. and $\mathrm{Hu}$, FB. (2010). Leptin and soluble leptin receptor levels in plasma and risk of type 2 diabetes in U.S. women: A prospective study. Diabetes, 59(3):611-8. 
Velasque, MT.; Bhathena, SJ. and Hansen, CT. (2001). Leptin and its relation to obesity and insulin in the SHR/N-corpulent rat, a model of type II diabetes mellitus. Int $\mathrm{J}$ Exp Diabetes Res., 2:217-223.

Viikari, LA.; Huupponen, RK.; Viikari, JS.; Marniemi, J.; Carita, Eklund C.; Hurme, M.; Lehtima," ki T.; Kivima," ki M. and Raitakari, OT. (2007). Relationship between leptin and Creactive protein in young Finnish adults. J Clin Endocrinol Metab, 92: 4753 - 4758.

Wannamethee, SG.; Tchernova, J.; Whincup, P. (2007). Plasma leptin: associations with metabolic, inflammatory and haemostatic risk factors for cardiovascular disease. Atherosclerosis., 191(2):418-426.

Welsh, P.; Murray, HM.; Buckley, BM.; de Craen AJM.; Ford, I.; Jukema, JW.; Macfarlane, PW.; Packard, CJ.; Stott, DJ.; Westendorp, RGJ.; Shepherd, J. and Sattar, N. (2009). Leptin predicts diabetes but not cardiovascular disease: results from a large prospective study in an elderly population. Diabetes Care, 32: 308-310.

\section{ARABIC SUMMARY}

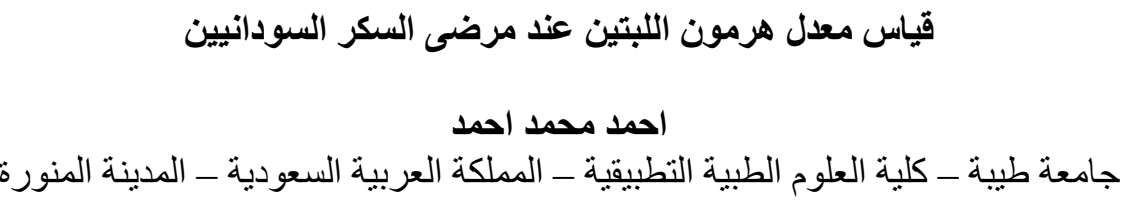

جامعة طيبة ـ كلية العلوم الطبية التطبيقية ـ المملكة العربية السعودية ــ المدينة المنورة

هرمون بروتيني، ينتجه ويفرزه النسيج الدهني خاصة النسيج الدهني الأبيض. ويلعب الهابـ الهرمون دوراً

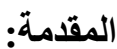

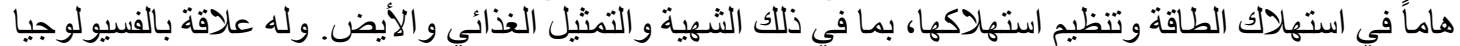

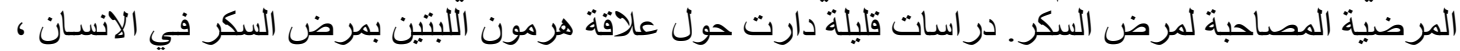

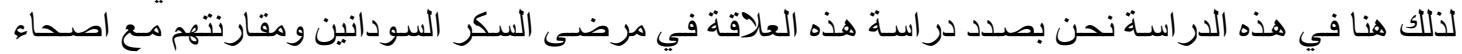

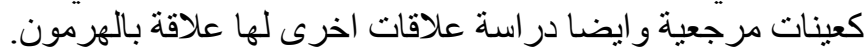

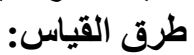

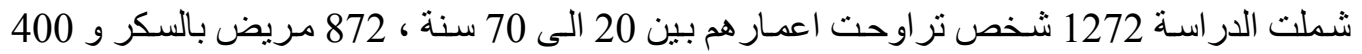

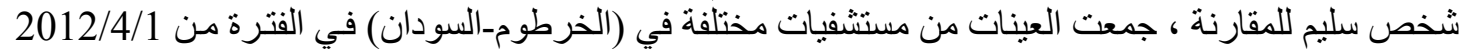
و الى 2012/9/1. نم قياس مستوى هرمون اللبتين، الكولسيترول مـع اخذ في الاعتبار معدل السمنة، التدخين و في التين

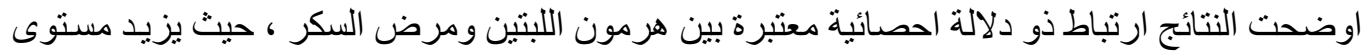

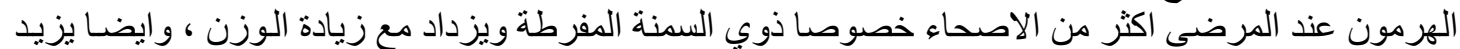

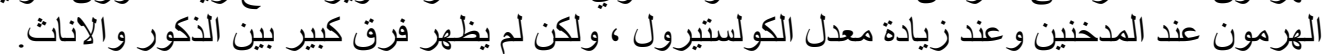

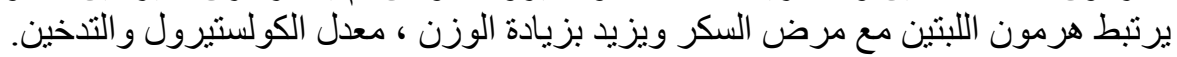

